\title{
MODELAGEM DA COPA DE ÁRVORES DE EUCALIPTO EMPREGANDO REDES NEURAIS ARTIFICIAIS
}

\author{
Rosália Nazareth Rosa Trindade ${ }^{1}$ \\ Vinícius Faúla Aguiar ${ }^{2}$ \\ Eduardo Henrique Mendes Alves ${ }^{3}$ \\ Tamires Mousslech Andrade Penido ${ }^{4}$ \\ Victor Duarte Vieira ${ }^{5}$ \\ Bruno Oliveira Lafetá ${ }^{6}$ \\ Márcio Takeshi Sugawara ${ }^{7}$
}

Resumo: O objetivo foi avaliar a eficiência da estimação simultânea de índices morfométricos da copa de árvores de eucalipto em um plantio adensado empregando RNA. Foram estabelecidas três parcelas experimentais em uma plantação de eucalipto localizada no IFMG - campus de São João Evangelista. Realizou-se o inventário florestal aos 37 meses de idade. Calculou-se para cada árvore três índices morfométricos de copa. Foram treinadas 400 RNA para estimar simultaneamente os índices, sendo 200 Multilayer Perceptron (MLP) e 200 Radial Basis Function (RBF). Uma desvantagem observada foi a perda na precisão das estimativas de formal da copa, fato que pode ser atribuído a maior variabilidade dos valores observados (CV de $48 \%$ ) e à sua tendência linear constante. Conclui-se que a modelagem por RNA com arquiteturas MLP e RBF demonstraram adequabilidade e precisão para estimar os índices morfométricos proporção da copa e índice de abrangência, respectivamente.

Palavras-chave: Formal da copa; Índice de abrangência; Inteligência artificial; Proporção da copa.

\footnotetext{
1 Departamento de Engenharia Florestal/Universidade Federal dos Vales do Jequitinhonha e Mucuri, Brasil. Email: rosalia.trindade22@gmail.com.

2 Engenharia Florestal/Instituto Federal de Educação, Ciência e Tecnologia de Minas Gerais, Brasil. Email: vinicius.aguiar.agr@gmail.com.

3 Engenharia Florestal/Instituto Federal de Educação, Ciência e Tecnologia de Minas Gerais, Brasil. Email: eduardohma1996@gmail.com.

4 Departamento de Engenharia Florestal/Universidade Federal dos Vales do Jequitinhonha e Mucuri, Brasil. Email: penidotma@gmail.com.

5 Departamento de Engenharia Florestal/Universidade Federal dos Vales do Jequitinhonha e Mucuri, Brasil. Email: victorduarte.vdv@gmail.com.

6 Departamento de Engenharia Florestal/Universidade Federal dos Vales do Jequitinhonha e Mucuri, Brasil. Email: bruno.lafeta@ifmg.edu.br.

7 Departamento de Engenharia Florestal/Universidade Federal dos Vales do Jequitinhonha e Mucuri, Brasil. Email: marcio.takeshi@ifmg.edu.br.
} 